\title{
КОМПЛЕКСНЫЕ НАУЧНЫЕ ИССЛЕДОВАНИЯ РУИН УСАДЬБЫ «НАДНЁМАН» В Д. НАДНЁМАН УЗДЕНСКОГО РАЙОНА МИНСКОЙ ОБЛАСТИ КАК ОБЪЕКТА ИСТОРИКО-КУЛЬТУРНОГО НАСЛЕДИЯ
}

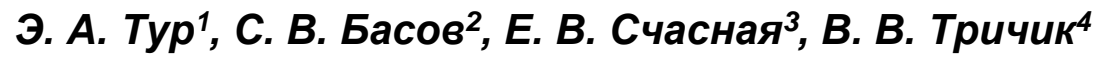 \\ ${ }^{1}$ K. т. н., заведующий кафеерой инженерной экологии и химии \\ учреждения образования «Брестский государственный технический университет» \\ ${ }^{2}$ К. т. н., доцент кафредры инженерной экологии и химии \\ учреждения образования «Брестский государственный технический университет» \\ ${ }^{3}$ Главный архитектор проекта ПМ-2 УП «Институт Гродногражданпроект» \\ ${ }^{4}$ Студентка группы Д-23 строительного факультета учреждения образования \\ «Брестский государственный технический университет»
}

\begin{abstract}
Реферат
Историко-культурное наследие Республики Беларусь является достоянием белорусского народа. Важнейшей частью проекта по реконструкции и реставрации объектов, включенных в Перечень недвижимых объектов историко-культурного наследия, является раздел «Комплексные научные исследования». В данной работе были изучены образцы строительных растворов и окрасочных составов, отобранные с различных участков руин усадьбы в д. Наднёман. Целью исследования являлось изучение особенностей исходных штукатурных и кладочных растворов, определение первоначальных окрасочных составов и разработка методических рекомендаций по проведению ремонтнореставрационных работ. Объект был обследован должным образом, определены аутентичные строительные растворы и окрасочные составы.
\end{abstract}

Ключевые слова: историко-культурное наследие, реставрация, комплексные научные исследования, окрасочные материалы, штукатурные и кладочные растворы

\section{A COMPREHENSIVE STUDY OF THE RUINS OF THE MANOR "NADNEMAN" IN D. NADNEMAN UZDA DISTRICT, MINSK REGION AS AN OBJECT OF HISTORICAL AND CULTURAL HERITAGE}

\section{Abstract}

\section{E. A. Tur, S. V. Basov, E. V. Scasnaya, V. V. Trichyk}

The historical and cultural heritage of the Republic of Belarus is the property of the Belarusian people. The most important part of the project for the reconstruction and restoration of objects included in the List of immovable objects of Historical and Cultural Heritage is the section "Complex scientific research". In this work, we studied samples of building mortars and paint compositions taken from various sites of the ruins of the estate in the village of Nadneman. The purpose of the study was to study the characteristics of the initial plaster and masonry solutions, to determine the initial paint compositions and to develop methodological recommendations for carrying out repair and restoration work. The object was properly examined, authentic building solutions and paint compositions were determined.

Keywords: historical and cultural heritage, restoration, comprehensive scientific research, painting materials, plaster and masonry mortars

\section{Введение}

Важнейшей частью проекта по реконструкции и реставрации объектов, включенных в Перечень недвижимых объектов историкокультурного наследия Республики Беларусь, является раздел «Комплексные научные исследования». Он включает в себя архивную справку об объекте и результаты физико-химических исследований штукатурных и кладочных растворов, а также окрасочных составов, обнаруженных на отобранных пробах фасадов и/или внутренних поверхностей исследуемого объекта. В последние годы значительно возрос объем работ по реставрации и восстановлению зданий и сооружений, являющихся объектами историко-культурного наследия, а также объем проектных и изыскательских работ [1]. Загрязнение окружающей среды привело к изменению механизмов деструктивных процессов в конструкционных и отделочных строительных материалах памятников архитектуры [2].

Кроме того, наблюдается снижение качества работ по сохранению зданий из-за неудачного выбора реставрационных материалов, возрастает риск утраты ценнейших элементов архитектурноисторической среды городов, а обострение экологической ситуации проявляется возникновением проблем сохранения памятников архитектуры различных исторических периодов $[3,4,5]$.

Многие десятилетия из-за отсутствия средств реставрация зданий в большинстве случаев сводилась лишь к легкому косметическому ремонту. Неоднократные ремонты привели к образованию многослойного «пирога» из цементной, известковой штукатурки и различных по качеству других отделочных материалов. Однако, не устранив первопричину, невозможно приостановить процессы разрушения отделки здания.

Ремонтно-реставрационные работы, как правило, начинаются с комплексного технического обследования зданий. При проведении обследования очень часто выясняется, что, кроме реставрации самого фасада здания, необходимо выполнить комплекс работ по усилению фундамента и устройству гидроизоляции в подвальных помещениях, по устранению причин капиллярного подсоса влаги в ограждающие конструкции здания или сооружения $[2,6,7]$.

Историко-культурное наследие Республики Беларусь является достоянием белорусского народа и неотъемлемой частью достижений мировой цивилизации. Необходимость его сохранения несомненна. Историко-культурное наследие представляет собой важнейший источник творческих сил народа, выступает эффективным средством национального развития, создания полноценных условий совершенствования личности.

Сохранение историко-культурного наследия имеет и огромное практическое значение для современников. Историко-культурной ценностью признаются объекты, обладающие совокупностью двух признаков: культурной значимостью и юридическим признанием в таком качестве посредством включения в охранный реестр - Государственный список историко-культурных ценностей Республики Беларусь. Компоненты, включенные в термин «историко-культурные ценности», входят в понятие «историко-культурное наследие». Наличие историко-культурных объектов может способствовать дальнейшему развитию сферы туризма в Республике Беларусь. 
История усадьбы Наднёман связана с жизнью, деятельностью и научными открытиями талантливого белорусского ученого-естествоиспытателя Якуба Наркевича-Иодко.

Руины бывшего поместья в деревне Наднёман являются памятником архитектуры неоготики (рисунок 1) и включёны в Государственный список историко-культурных ценностей Республики Беларусь.

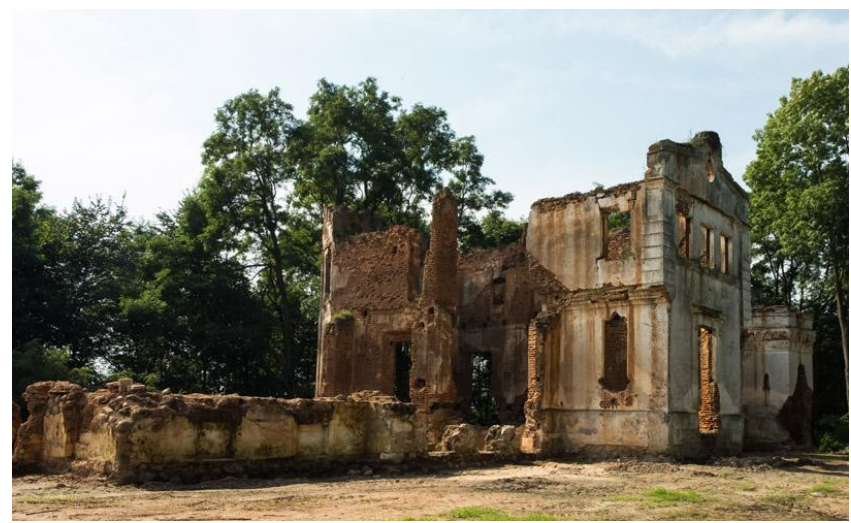

Рисунок 1 - Руины усадьбы Наднёман

В 1823 году шляхтич Онуфрий Наркевич-Иодко выкупил имение Малысковщина, на территории которого находился бровар (двухэтажный пивоваренный завод). Спустя десятилетие здание приобрело завершенный вид и стало занятным примером транссрормации промышленного сооружения в жилое поместье. Усадьба характеризовалась смешением противоположных стилей: оборонительных сооружений и утонченной средневековой готики. Композиция строения включала в себя две башни шестигранной и четырехгранной формы, широкую террасу и лестничные каскады (рисунок 2).

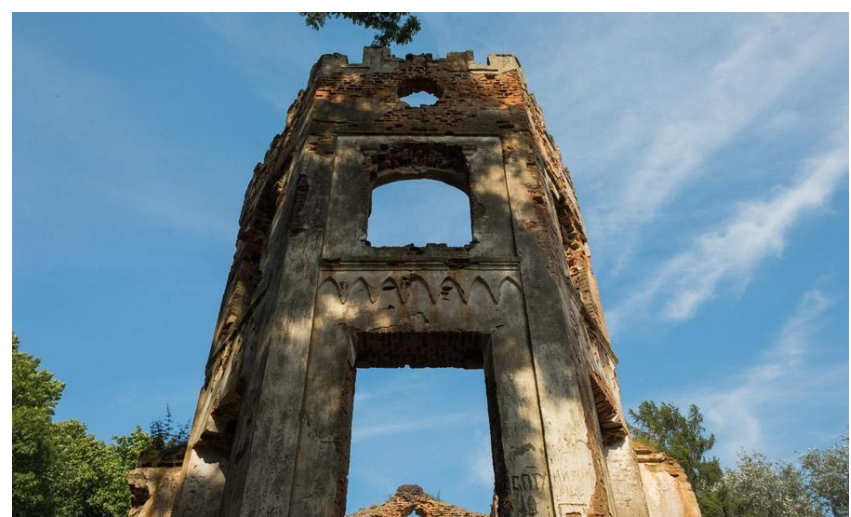

Рисунок 2 - Руины шестигранной башни

После смерти Онуфрия поместье унаследовал его сын - естествоиспытатель, врач, профессор электрографии и магнетизма Якуб Наркевич-Иодко. Чуть позднее прямо на территории усадьбы ученый создал первую в Беларуси метеорологическую станцию.

Известно, что в имении проводились прогрессивные эксперименты, связанные с использованием электричества в разных сферах жизни. С именем Якуба Наркевича-Иодко связывают масштабные исследования по использованию электромагнитного излучения в медицине. В период расцвета поместье в деревне Наднеман славилось далеко за пределами Беларуси: помимо прочего, здесь работала бесплатная лечебница (прототип современного санатория), где оказывалась безвозмездная помощь малоимущим сельчанам. Благодаря своим опытам в середине 1890 годов Якуб НаркевичИодко смог разработать новый метод лечения - электротерапию, которая с успехом применялась в клиниках Рима, Парижа и Флоренции. Лечение электричеством дополнялось магнито- и гипнотерапией, гимнастикой, оздоровлением местными минеральными водами.

В начале XX века усадьба в деревне Наднеман медленно приходит в запустение. Отъезд последнего владельца Конрада
Наркевича-Иодко предрешает судьбу этого удивительного места. После революции поместье грабят: утеряна не только уникальная библиотека, но и дорогое научное оборудование. Некоторое время в стенах усадьбы существует детский санаторий, позже здание взрывают партизаны. В 1995 году заканчивается эпохальная история Наднемана: рушатся последние остатки главной башни.

На сегодняшний день поместье заброшено и остро нуждается в консервации: сохранились руины центральной части строения (рисунок 3) и въездная брама имения (рисунок 4).

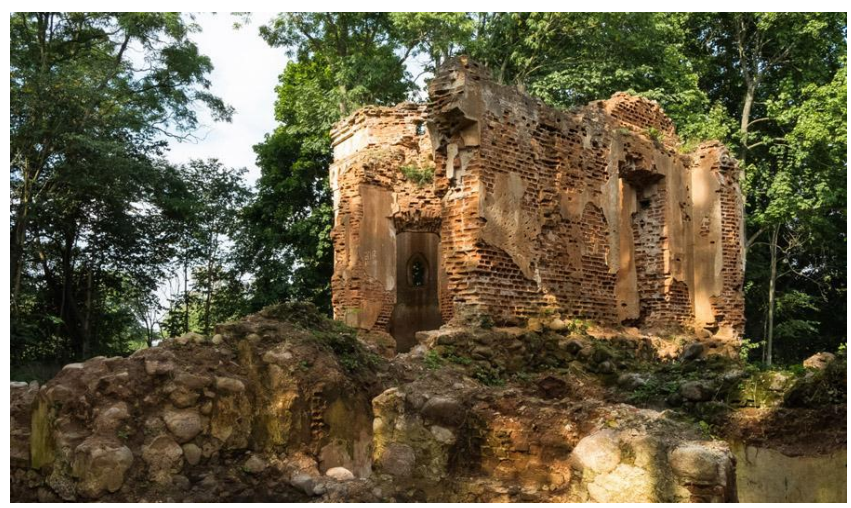

Рисунок 3 - Руины центральной части строения

\section{Основная часть}

В 2019-2020 гг. авторами были проведены физико-химические исследования строительных растворов, материалов и окрасочных составов руин бывшего поместья в деревне Наднёман. Цель исследования - изучение физико-химических и технологических особенностей исходных штукатурных растворов, определение первоначальных окрасочных составов и разработка методических рекомендаций по проведению реставрационных работ на фасадах здания в рамках комплексных научных исследований. Для анализа представленных образцов применяли микрохимический, гранулометрический и петрографический методы исследований $[1,2,3,7]$. Гранулометрический состав заполнителей определялся путем просеивания через сита с размером ячеек 2, 1, 0,5, 0,25, 0,125, 0,063 мм согласно рекомендациям ОАО «Белреставрация» Министерства Культуры Республики Беларусь (для создания аутентичных строительных растворов недвижимых объектов историко-культурного наследия 1 и 2 категории). Цвета лакокрасочных покрытий и отделочных составов указаны по каталогу «3D pius» компании CAPAROL. Цвет покрытия определялся путём визуального сравнения образца с эталонной типографской выкраской. Для устранения метамерии определение цвета проводилось при рассеянном естественном освещении [3].

На исследования были представлены штукатурные и кладочные известково-песчаные растворы. Отдельные растворы (предположительно одного исторического периода) очень близки по соотношению компонентов и гранулометрическому составу заполнителя (кварцевого песка). Но некоторые растворы (предположительно различного исторического периода) значительно отличаются соотношением компонентов и гранулометрическим составом заполнителя (кварцевого песка).

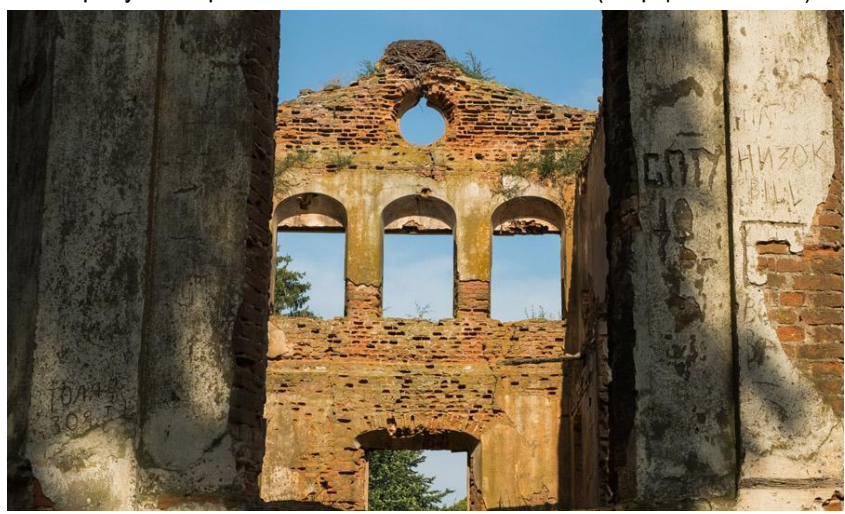

Рисунок 4 - Руины въездной брамы имения 
Вестник Брестского государственного технического университета. 2021

В результате исследований было проведено сравнение кладочных растворов, отобранных с правого крыла руин здания (историческая часть и более поздний период).

- К Кладочный раствор ЗКР-4 (стена правого крыла по оси 8, возле оси Д, уровень верха обрушенной стены подвала - историческая часть): известково-песчаный раствор серого цвета состава с количественным соотношением компонентов 1:6. В качестве заполнителя использовался разнозернистый песок преимущественно средней (размер зерна 0,5-0,25 мм) фрракции. Особенности раствора: содержание фракции с размером зерна 0,5-0,25 мм составило около - 46,0 \% от массы заполнителя, фракции с размером зерна 0,25-0,125 мм - около 18,0 \%, фрракции с размером зерна 1,0-0,5 мм - около 35,0\%. Содержание фракции с размером частиц более 1 мм составило 1,0\%. Минеральный состав заполнителя полевошпатово-кварцевый, в основном, кварцевый песок. pH водной вытяжки около 8,70 (без особенностей).

- Кладочный раствор ЗКР-3 (правое крыло, северный фасад, наружная стена подвала по оси В - более поздний исторический период): известково-песчаный раствор серого цвета состава с количественным соотношением компонентов 1:4. В качестве заполнителя использовался разнозернистый песок преимущественно средней (размер зерна 0,5-0,25 мм) фракции. Особенности раствора: содержание фрракции с размером зерна 0,5-0,25 мм составило около 55,0 \% от массы заполнителя, фракции с размером зерна 0,25-0,125 мм - около 19,0 \%, фрракции с размером зерна 1,0-0,5 мм - около $25,0 \%$, фракции с размером частиц более 1 мм - 0,7 \%, фракции с размером частиц более 2,0 мм - 0,3 \%. Минеральный состав заполнителя полевошпатово-кварцевый, в основном, кварцевый песок. рН водной вытяжки около 8,91 (без особенностей).

При сравнении двух данных кладочных растворов следует отметить различное соотношение компонентов «известь:песок» (1:6 у раннего раствора и 1:4 у более позднего раствора). Кроме того, имеются большие различия в гранулометрическом составе заполнителя (кварцевого песка) по всем фрракциям (таблица 1): у раннего состава присутствует на $9 \%$ меньше средней $(0,5-0,25$ мм) фракции и на $10 \%$ больше крупной - (1,0-0,5 мм) фракции заполнителя. Кроме того, у более позднего состава встречается небольшое количество (около 0,3 \%) включений полевого шпата размером более 2 мм. Это говорит о том, что в различные исторические периоды кварцевый песок для кладочных работ был привезен из разных карьеров.

Кроме того, согласно физико-химическим исследованиям прошлых лет $[8,9,10,11,12]$, для ранних построек характерно применение «бедных» кладочных растворов (таких как кладочный раствор ЗКР-4 (историческая часть) с соотношением компонентов «известь:песок» $=1: 6$ ). В более поздний исторический период на территории Республики Беларусь (не только в Минской, но и в Брестской и Гродненской областях) применялись более «богатые» известью кладочные растворы с соотношением компонентов «известь:песок» $=1: 3-1: 4[8,9,10,11,12]$. Также для составов более раннего исторического периода объектов Республики Беларусь характерно применение песков с повышенным содержанием крупной фрракции 1,0-0,5 мм [8, 9, 10, 11, 12], (в данном случае как в кладочном растворе, отобранном с исторической части здания (таблица 1)).

Таблица 1 - Сравнительный анализ гранулометрического состава заполнителя

\begin{tabular}{|c|c|c|c|c|c|}
\hline \multirow{2}{*}{$\begin{array}{c}\text { Кладочный } \\
\text { раствор }\end{array}$} & \multicolumn{5}{|c|}{$\begin{array}{c}\text { Гранулометрический } \\
\text { состав заполнителя } \\
\text { (кварцевого песка) по фракциям, \% }\end{array}$} \\
\cline { 2 - 6 } & $\begin{array}{c}0,25- \\
0,125 \mathrm{~mm}\end{array}$ & $\begin{array}{c}0,5- \\
0,25 \mathrm{~mm}\end{array}$ & $\begin{array}{c}1,0- \\
0,5 \mathrm{~mm}\end{array}$ & $\begin{array}{c}\text { более } \\
1,0 \mathrm{~mm}\end{array}$ & $\begin{array}{c}\text { более } \\
2,0 \mathrm{~mm}\end{array}$ \\
\hline $\begin{array}{c}\text { 3КР-4 } \\
\text { (историческая } \\
\text { часть) }\end{array}$ & 18,0 & 46,0 & 35,0 & 1,0 & - \\
\hline $\begin{array}{c}\text { 3КР-3 (более } \\
\text { поздний } \\
\text { период) }\end{array}$ & 19,0 & 55,0 & 25,0 & 0,7 & 0,3 \\
\hline
\end{tabular}

Авторами также было проведено сравнение штукатурных растворов, отобранных с различных мест сохранившихся руин здания.

- Образец ЗШС-8 - Зондаж штукатурного раствора. Поле стены. Северный фасад по оси Б, возле оси на уровне 1-го этажа (историческая часть): известково-песчаный раствор серого цвета состава с количественным соотношением компонентов 1:4. В качестве заполнителя использовался разнозернистый песок преимущественно средней (размер зерна 0,5-0,25 мм) фракции. Особенности раствора: содержание фракции с размером зерна 0,5-0,25 мм составило около $62,0 \%$ от массы заполнителя, фракции с размером зерна 0,25-0,125 мм - около 10,0 \%, фракции с размером зерна 1,0-0,5 мм - около 28,0 \%. Содержание фракции с размером частиц более 1 мм составило 1,0\%. Минеральный состав заполнителя полевошпатово-кварцевый, в основном, кварцевый песок. рН водной вытяжки около 8,94.

- Образец ЗШС-6 - Зондаж штукатурного раствора. Поле стены 6-гранной башни - каплицы. Северный фасад по оси 10 на уровне 1-го этажа (более поздний исторический период): известковопесчаный раствор серого цвета состава с количественным соотношением компонентов 1:3. В качестве заполнителя использовался разнозернистый песок преимущественно средней (размер зерна 0,5-0,25 мм) фракции. Особенности раствора: содержание фракции с размером зерна 0,5-0,25 мм составило около 59,0 \% от массы заполнителя, фракции с размером зерна 0,25-0,125 мм около 23,0 \%, фракции с размером зерна 1,0-0,5 мм - около 18,0 \%. Фракция с размером частиц более 1 мм отсутствует. Минеральный состав заполнителя полевошпатово-кварцевый, в основном, кварцевый песок. рН водной вытяжки около 8,82.

При сравнении двух данных штукатурных растворов следует отметить различное соотношение компонентов «известь:песок» (1:4 у раннего раствора и 1:3 у более позднего раствора). Кроме того, имеются большие различия в гранулометрическом составе заполнителя (кварцевого песка) по всем фрракциям (таблица 2): у раннего состава присутствует на $13 \%$ меньше мелкой $(0,25-0,125$ мм) фракции, на 3,0 \% больше средней (0,5-0,25 мм) фракции и на $10 \%$ больше крупной (0,5-0,25 мм) фракции заполнителя. Кроме того, у раннего состава встречается небольшое количество (около 1,0 \%) включений полевого шпата размером более 1 мм. Это говорит о том, что в различные исторические периоды кварцевый песок для производства штукатурных работ был также привезен из разных карьеров, как и песок для кладочных работ.

Таблица 2 - Сравнительный анализ гранулометрического состава заполнителя

\begin{tabular}{|c|c|c|c|c|c|}
\hline \multirow{2}{*}{$\begin{array}{c}\text { Штукатурный } \\
\text { раствор }\end{array}$} & \multicolumn{5}{|c|}{ Гранулометрический } \\
\cline { 2 - 6 } & $\begin{array}{c}0,25- \\
0,125 \text { мм }\end{array}$ & $\begin{array}{c}0,5- \\
0,25 \text { мм }\end{array}$ & $\begin{array}{c}1,0- \\
0,5 \text { мм }\end{array}$ & $\begin{array}{c}\text { более } \\
1,0 \text { мм }\end{array}$ & $\begin{array}{c}\text { более } \\
2,0 \text { мм }\end{array}$ \\
\hline $\begin{array}{c}\text { 3ШС-8 } \\
\text { (историческая } \\
\text { часть) }\end{array}$ & 10,0 & 62,0 & 28,0 & 1,0 & - \\
\hline $\begin{array}{c}\text { 3ШС-6 } \\
\text { (более поздний } \\
\text { период) }\end{array}$ & 23,0 & 59,0 & 18,0 & - & - \\
\hline
\end{tabular}

Также для штукатурных составов более раннего исторического периода характерно применение песков с повышенным содержанием крупной фракции 1,0-0,5 мм [8, 9, 10, 11, 12], в данном случае как в штукатурном растворе, отобранном с исторической части руин здания (таблица 2).

Для сравнения и анализа все составы исследованных строительных растворов сведены в таблицу 3. При необходимости возможно изготовление на строительной площадке каждого конкретного штукатурного или кладочного раствора, пользуясь данной таблицей. 
Вестник Брестского государственного технического университета. 2021

Таблица 3 - Составы исследованных минеральных растворов

\begin{tabular}{|c|c|c|c|c|c|c|}
\hline \multirow{2}{*}{$\begin{array}{c}\text { Наименование } \\
\text { раствора }\end{array}$} & \multirow{2}{*}{$\begin{array}{l}\text { Соотношение } \\
\text { известь:песок }\end{array}$} & \multicolumn{5}{|c|}{ Гранулометрический состав по фракциям , \% } \\
\hline & & $0,25-0,125 \mathrm{mM}$ & $0,5-0,25 \mathrm{MM}$ & $1,0-0,5 \mathrm{MM}$ & более 1,0 мм & более 2,0 мм \\
\hline \multicolumn{7}{|c|}{ Усадебный дом. Штукатурные растворы } \\
\hline ЗШС-1 & 1:5 & 16,0 & 55,0 & 27,0 & 1,0 & 1,0 \\
\hline ЗШС-2 & $1: 6-1: 6,5$ & 21,0 & 66,0 & 12,5 & 0,5 & - \\
\hline ЗШС-3 & $1: 5$ & 12,0 & 52,0 & 35,0 & 1,0 & - \\
\hline ЗШС-4 & $1: 4$ & 16,5 & 58,0 & 24,5 & 1,0 & - \\
\hline ЗШС-5 & $1: 5-1: 5,5$ & 21,0 & 52,0 & 26,0 & 1,0 & - \\
\hline ЗШС-6 & $1: 3$ & 23,0 & 59,0 & 18,0 & - & - \\
\hline ЗШС-7 & $1: 5$ & 15,0 & 57,0 & 27,0 & 1,0 & - \\
\hline ЗШС-8 & $1: 4$ & 10,0 & 62,0 & 28,0 & 1,0 & - \\
\hline 3ШС-9 & $1: 4$ & 33,0 & 58,0 & 9,0 & - & - \\
\hline ЗШС-10 & $1: 7$ & 12,0 & 49,0 & 37,5 & 1,5 & - \\
\hline ЗШС-11 & $1: 4,5-1: 5$ & 28,0 & 53,5 & 17,5 & 1,0 & - \\
\hline 3ШС-12 & $1: 5$ & 19,5 & 51,0 & 28,0 & 1,5 & - \\
\hline \multicolumn{7}{|c|}{ Усадебный дом. Кладочные растворы } \\
\hline 3КС-1 & $1: 4$ & 14,0 & 46,0 & 38,0 & 2,0 & - \\
\hline 3КР-1 & $1: 4$ & 19,0 & 54,0 & 26,0 & 0,8 & 0,2 \\
\hline 3КР-3 & $1: 4$ & 19,0 & 55,0 & 25,0 & 0,7 & 0,3 \\
\hline 3КР-4 & 1:6 & 18,0 & 46,0 & 35,0 & 1,0 & - \\
\hline \multicolumn{7}{|c|}{ Оранжерея. Штукатурные растворы } \\
\hline ЗШС-1 & $1: 8$ & 24,0 & 36,0 & 28,0 & 4,5 & 7,5 \\
\hline ЗШС-2 & $1: 5$ & 20,0 & 48,0 & 29,0 & 2,5 & 0,4 \\
\hline 3ШС-3 & $1: 4-1: 4,5$ & 20,0 & 51,0 & 27,0 & 1,5 & 0,5 \\
\hline \multicolumn{7}{|c|}{ Оранжерея. Кладочные растворы } \\
\hline 3КР-1 & $1: 7-1: 8$ & 27,0 & 63,5 & 9,0 & 0,5 & - \\
\hline 3КР-2 & $1: 10$ & 14,0 & 56,0 & 29,0 & 1,0 & - \\
\hline
\end{tabular}

Результаты исследования лицевых поверхностей стен усадебного дома и оранжереи представлены в таблице 4.

Таблица 4 - Исследования лицевых поверхностей стен усадебного дома и оранжереи

\begin{tabular}{|c|c|c|}
\hline $\begin{array}{c}\text { Наименование исследованных } \\
\text { лицевых поверхностей }\end{array}$ & $\begin{array}{c}\text { Цвет окрасочного состава } \\
\text { (визуально) и основа состава }\end{array}$ & $\begin{array}{c}\text { Цвет окрасочного состава } \\
\text { по архитектурному каталогу «3D pius» }\end{array}$ \\
\hline \multicolumn{3}{|c|}{ Усадебный дом } \\
\hline $\begin{array}{c}\text { Лицевая поверхность стены } \\
\text { подвала внутренней, правое крыло }\end{array}$ & $\begin{array}{c}\text { Темный красно-коричневый цвет, } \\
\text { на минеральной основе }\end{array}$ & Близок к образцу «Рарауа 100» \\
\hline $\begin{array}{c}\text { Лицевая поверхность стены } \\
\text { подвала внутренней, левое крыло }\end{array}$ & $\begin{array}{c}\text { Коричневый цвет, } \\
\text { на минеральной основе }\end{array}$ & Близок к образцу «Amber 40» \\
\hline Лицевая поверхность цоколя ризалита, южный фасад & $\begin{array}{c}\text { Бежевый цвет, } \\
\text { на минеральной основе }\end{array}$ & Близок к образцу «Amber 115» \\
\hline $\begin{array}{c}\text { Лицевая поверхность поля } \\
\text { стены } 1 \text { этажа - ризалит, южный фасад }\end{array}$ & $\begin{array}{l}\text { Светло-бежевый цвет, } \\
\text { на минеральной основе }\end{array}$ & Близок к образцу «Marill 120» \\
\hline Лицевая поверхность цоколя (ниша), южный фасад & $\begin{array}{c}\text { Бежевый цвет, } \\
\text { на минеральной основе }\end{array}$ & Близок к образцу «Marill 115» \\
\hline $\begin{array}{c}\text { Лицевая поверхность поля стены 6-гранной башни - } \\
\text { каплицы, северный фасад на уровне 1-го этажа }\end{array}$ & $\begin{array}{l}\text { Светло-коричневый цвет, } \\
\text { на минеральной основе }\end{array}$ & Близок к образцу «Amber 80» \\
\hline $\begin{array}{c}\text { Лицевая поверхность стены } \\
\text { внутри каплицы, на уровне 1-го этажа }\end{array}$ & $\begin{array}{l}\text { Темный красно-коричневый цвет, } \\
\text { на минеральной основе }\end{array}$ & Близок к образцу «Рарауа 100» \\
\hline $\begin{array}{c}\text { Лицевая поверхность поля стены северного фасада } \\
\text { на уровне 1-го этажа (историческая часть) }\end{array}$ & $\begin{array}{l}\text { Светло-бежевый цвет, } \\
\text { на минеральной основе }\end{array}$ & Близок к образцу «Siena 120» \\
\hline Лицевая поверхность цоколя - ризалита & $\begin{array}{c}\text { Бежевый цвет, } \\
\text { на минеральной основе }\end{array}$ & Близок к образцу «Siena 115» \\
\hline $\begin{array}{l}\text { Лицевая поверхность пристройки, } 1 \text { этаж, } \\
\text { справа - наружная стена северного фрасада }\end{array}$ & $\begin{array}{l}\text { Светло-бежевый цвет, } \\
\text { на минеральной основе }\end{array}$ & Близок к образцу «Siena 120» \\
\hline $\begin{array}{l}\text { Лицевая поверхность наружной } \\
\text { стены южного фасада, } 1 \text { этаж }\end{array}$ & Не окрашена & - \\
\hline $\begin{array}{c}\text { Лицевая поверхность поля стены } \\
\text { 1-го этажа северного фрасада }\end{array}$ & $\begin{array}{l}\text { Серо-коричневый цвет, } \\
\text { на минеральной основе }\end{array}$ & Близок к образцу «Ceramic 15» \\
\hline \multicolumn{3}{|c|}{ Оранжерея } \\
\hline Лицевая поверхность поля части наружной стены & $\begin{array}{l}\text { Светло-коричневый цвет, } \\
\text { на минеральной основе }\end{array}$ & Близок к образцу «Amber 85» \\
\hline $\begin{array}{l}\text { Лицевая поверхность поля стены, } \\
\text { перпендикулярной предыдущей }\end{array}$ & $\begin{array}{l}\text { Темно-бежевый цвет, } \\
\text { на минеральной основе }\end{array}$ & Близок к образцу «Amber 115» \\
\hline Лицевая поверхность поля внутренней части стены & $\begin{array}{l}\text { Темно-бежевый цвет, } \\
\text { на минеральной основе }\end{array}$ & Близок к образцу «Amber 115» \\
\hline
\end{tabular}

Исследования аутентичной цветовой гаммы представленных образцов, отобранных с поверхностей стен усадебного дома, дали следующие результаты:

- Первоначально внутренняя стена подвала правого крыла была окрашена составом коричневато-бежевого цвета на минеральной основе. Цвет близок к образцу «Amber 115».
- Первоначально внутренняя стена подвала левого крыла - была окрашена составом светло-бежевого цвета на минеральной основе. Цвет близок к образцу «Marill 120».

- Первоначально цоколь ризалита южного фасада - был окрашен составом бежевого цвета на минеральной основе. Цвет близок к образцу «Amber $115 »$. 
Вестник Брестского государственного технического университета. 2021

- Первоначально поле стены 1 этажа - ризалит южного фасада было окрашено составом светло-бежевого цвета на минеральной основе. Цвет близок к образцу «Marill $120 »$.

- Первоначально цоколь (ниша) южного фасада - был окрашен составом светло-бежевого цвета на минеральной основе. Цвет близок к образцу «Marill 120».

- Первоначально поле стены 6-гранной башни - каплицы северного фасада на уровне 1-го этажа - было окрашено составом светло-коричневого цвета на минеральной основе. Цвет близок к образцу «Amber 80».

- Первоначально стена внутри каплицы, на уровне 1-го этажа была окрашена составом светло-бежевого цвета на минеральной основе. Цвет близок к образцу «Amber 120».

- Первоначально поле стены северного фрасада уровне 1-го этажа (историческая часть) были окрашены составом светло-бежевого цвета на минеральной основе. Цвет близок к образцу «Palazzo 180».

- Первоначально цоколь - ризалит - был окрашен составом коричневато-бежевого цвета на минеральной основе. Цвет близок к образцу «Amber 115».

- Первоначально пристройка, 1 этаж, справа - наружная стена северного фасада - была окрашена составом молочно-бежевого цвета на минеральной основе. Цвет близок к образцу «Curry 30».

- Установить, как первоначально была окрашена поверхность наружной стены южного фасада не представилось возможным. Окрасочный состав не сохранился.

- Первоначально поверхность поля стены 1-го этажа северного фасада была окрашена составом светло-бежевого цвета на минеральной основе. Цвет близок к образцу «Marill 120».

Исследования штукатурных растворов с фрагментами окрасочных составов, отобранных с поверхностей стен оранжереи, показали следующие результаты:

- Первоначально поле наружной стены было окрашено составом светло-коричневого цвета на минеральной основе. Цвет близок к образцу «Amber 85»

- Первоначально поле стены (отдельный фрагмент) было окрашено составом темно-бежевого цвета на минеральной основе. Цвет близок к образцу «Amber 115».

- Первоначально поле внутренней части стены было окрашено составом темно-бежевого цвета на минеральной основе. Цвет близок к образцу «Amber 115».

Здание неоднократно перекрашивалось составами на минеральной основе. Все штукатурные и кладочные работы производились известково-песчаными составами (без цемента). Следует отметить, что нижележащие окрасочные слои не удалялись должным образом. Первоначально усадебный дом и оранжерея были оштукатурены известково-песчаными растворами и окрашены минеральными составами.

При проведении ремонтно-реставрационных работ следует учитывать, что исследованные первоначальные штукатурные и кладочные растворы выполнены известково-песчаными составами, обладающими высокой пористостью, газо- и паропроницаемостью. В связи с этим к материалам, используемым при проведении ремонтно-реставрационных работ, предъявляются следующие требования: материаль по своим эксплуатационным характеристикам должны быть аналогичнь первоначальным; материалы должны быть химически совместимы с оригинальными и обладать высокой щелочестойкостью [1, 2, 3].

Проведению штукатурных и окрасочных работ должны предшествовать такие важнейшие работы, как воссоздание первоначального облика здания по сохранившимся в архивах чертежам, рисункам и фотографиям, устройство кровли, водосточных систем, а также работы по гидроизоляции здания $[1,6]$

Поэтому рекомендуется следующая схема проведения ремонтно-реставрационных работ:

1. Воссоздание первоначального облика здания (кирпичная кладка, устройство кровли, гидроизоляционные и другие строительные работы по восстановлению здания по разработанной проектной документации). Удаление всех имеющихся слоёв покрасочных составов а также деструктированных (разрушенных) фрагментов штукатурного слоя. Очистка поверхностей от продуктов биокоррозии.

2. Подготовка поверхности под покраску: восполнение утраченных фрагментов штукатурки, по необходимости - новые штукатурные работы; грунтование поверхности фасадов.

3. Окрашивание поверхности фасадов.

Кладочные работы рекомендуется проводить аутентичным кирпичом и бутовым камнем (или аналогом). Восстановление кирпичной кладки рекомендуется на известково-песчаном растворе M35F50 с защитным покрытием из цементно-песчаного раствора M100F100 Восстановление бутовой кладки рекомендуется на сложном раствоpe M50F50 с защитным покрытием из цементно-песчаного раствора M100F100. Возможно применение кладочных растворов зарубежных производителей, рекомендованных для реставрационных работ, с соответствующей прочностью на сжатие и морозостойкостью. Все отделочные слои фасада здания (штукатурку, окрасочные составы) следует механически удалить до основания. Для этого необходимо использовать жёсткие щётки, а также скребки и шпатели. Не допускается промывка поверхности холодной водой под давлением [2, 12].

Визуальное обследование представленных образцов выявило наличие на поверхности обширных пятен зелёного и чёрного цвета. Это говорит о высоком уровне микробной обсеменённости. На образцах с зелёной окраской предположительно преобладают микроскопические водоросли рода Pleurococcus, на образцах с чёрной окраской - микроскопические грибы рода Alternaria [5, 8, 9].

С целью удаления биологических загрязнений (мхов, грибов водорослей, плесени) и предотвращения их появления на минеральных строительных материалах, рекомендуются специально разработанные для этих целей составы [3, 5]:

1) обработка водоразбавляемым фунгицидным, альгицидным и бактерицидным средством, не содержащим фенола и солей тяжёлых металлов;

2) предварительная очистка поверхности специальным экологичным средством, не содержащим активного хлора и солей тяжёлых металлов с последующей обработкой бактерицидным, фунгицидным и альгицидным средством, не содержащим фенола, формальдегида и солей тяжёлых металлов.

Для восстановления штукатурного слоя рекомендуется использовать штукатурные смеси на основе известкового вяжущего, не содержащие цемента, обладающими водостойкостью, высокой паропроницаемостью и адгезией к основанию. В случае приготовления штукатурного раствора на строительной площадке следует использовать рецептуру раствора, определённую проведенными исследованиями. Рекомендуется использовать известь с содержанием активных $\mathrm{CaO}$ и $\mathrm{MgO}$ не менее $65 \%$. Песок должен соответствовать требованиям ГОСТа и быть отмыт от глинистых примесей $[1,2,12]$.

Для выравнивания неровно затёртой штукатурки и затирки микротрещин рекомендуется использовать известковую затирку на основе диспергированной белой извести, специально предназначенную для выполнения реставрационных работ по основаниям исторических зданий и памятников архитектуры.

Окрашивание поверхности следует проводить составами, формирующими покрытие с высокой паропроницаемостью и низким водопоглощением. Для этого в наибольшей степени подходят воднодисперсионные краски, модифицированные силиконовыми смолами и содержащие силикаты. Такие краски образуют наиболее микропористое покрытие, гидрофобное покрытие с низким грязеудержанием и могут наноситься на высокощелочные основания. Производить покраску фасадов рекомендуется не ранее, чем через 28 суток после выполнения всех подготовительных работ [2, 3]. При окраске восстановленных стен данного объекта не допустимо использование обычных водно-дисперсионных красок на основе акриловых полимеров. В этом случае может произойти омыление полимерного плёнкообразователя, что сопровождается шелушением краски, отслоением её от подложки и изменением первоначального цвета [2, 3, 12].

\section{Заключение}

Известково-песчаные кладочные и штукатурные растворы раннего и более позднего исторических периодов значительно отличались друг от друга как по соотношению компонентов, так и по гранулометрическому составу заполнителя. Аутентичные известково-песчаные кладочные растворы имели количественное соотношение компонентов известь:заполнитель $=1: 6$, а кладочные растворы более позднего исторического периода - 1:4. Кроме того, имелись большие различия в гранулометрическом составе заполнителя (кварцевого песка) по всем фракциям: у раннего состава присутствует на $9 \%$ меньше средней (0,5-0,25 мм) фракции и на $10 \%$ больше крупной (1,0-0,5 мм) фракции заполнителя. Кроме того, у более позднего состава встречается небольшое количество (около 0,3 \%) включений полевого шпата размером более 2 мм. Согласно физико-химическим исследованиям прошлых лет $[8,9,10,11,12]$ для ранних исторических построек характерно применение именно «бедных» кладочных растворов с соотношением компонентов известь:заполнитель = 1:6. 
Аутентичные известково-песчаные штукатурные растворы имели количественное соотношение компонентов известь:заполнитель от 1:4 до 1:7, а штукатурные растворы более позднего исторического периода - 1:3. Кроме того, обнаружены большие различия в гранулометрическом составе заполнителя (кварцевого песка) по всем фракциям: у раннего состава присутствует на $13 \%$ меньше мелкой $(0,25-0,125$ мм) фракции, на 3,0 \% больше средней $(0,5-0,25$ мм) фракции и на $10 \%$ больше крупной (0,5-0,25 мм) фракции заполнителя, а также встречается небольшое количество (около 1,0\%) включений полевого шпата размером более 1 мм.

Это позволяет предположить, что в различные исторические периоды кварцевый песок для кладочных и штукатурных работ был привезен из разных карьеров.

Здание неоднократно штукатурилось и перекрашивалось различными составами. Окрасочные работы и в раннее, и в более позднее время производились составами на минеральной основе. Первоначально здание было оштукатурено известково-песчаными растворами и окрашено минеральными составами.

Первоначально наружные стены были окрашены в бежево-коричневой цветовой гамме: стены усадебного дома - составом светлобежевого цвета на минеральной основе, близким к «Palazzo 180»; цоколь - составом коричневато-бежевого цвета, близким к «Amber 115»; стены 6-гранной башни-каплицы - составом светло-коричневого цвета, близким к «Amber 80»; пристройка - составом молочно-бежевого цвета, близким к «Curry 30». Отдельные фррагменты наружных стен были окрашены составом светло-бежевого цвета, близким к «Marill 120». Наружные стены оранжереи первоначально также были окрашены в бежевокоричневой цветовой гамме: фррагменты стен были попеременно окрашены составом светло-коричневого цвета, близким «Amber 85» и составом темно-бежевого цвета, близким к «Amber 115».

До проведения основных ремонтно-реставрационных работ по восстановлению стен объекта следует уделить внимание временным работам по гидрофобизации руин усадебного дома и оранжереи. Целью гидрофобизации является максимальная консервация сохранившихся участков и фррагментов, а также исключение протекания биологической коррозии, т. е. образования водорослей и мхов на поверхностях.

Сохранение историко-культурного наследия нашей страны является обязательной функцией современного государства и составляет одно из направлений его политики в сфрере культуры. Для решения проблем сохранения историко-культурного наследия необходимо более широко использовать общественные инициативы, осуществлять просветительскую деятельность, популяризацию национального исторического и культурного наследия Республики Беларусь.

\section{Список цитированных источников}

1. Ивлиев, А. А. Реставрационные строительные работы / А. А. Ивлиев, А. А. Калыгин. - М. : ПрофОбрИздат, 2001. - 272 с.

2. Фрёссель, Ф. Ремонт влажных и повреждённых солями строительных сооружений / Ф. Фрёссель. - М. : ООО «Пэйнт-медиа», 2006. $-320 \mathrm{c}$.

3. Брок, Т. Европейское руководство по лакокрасочным материалам и покрытиям / Т. Брок, М. Гротеклаус, П. Мишке. - пер. с англ. под ред. Л. Н. Машляковского. - М. : Пэйнт-Медиа, 2004. - 548 с.

4. Тур, Э. А. Исследование минеральных материалов, использованных при постройке дворцового комплекса Сапегов в Ружанах / Э. А. Тур, С. В. Басов // Вестник Брестского государственного технического университета. - Брест : БрГТУ, 2014. - № 1: Строительство и архитектура. - С. 88-91.

5. Тур, Э. А. Реставрация Коссовского дворца Пусловских и решение возникших при этом технических проблем / Э. А. Тур В. Н. Казаков, С. В. Басов // Вестник Брестского государственного технического университета. - 2017 - № 1: Строительство и архитектура. - С. 128-131.

6. Никитин, Н. К. Химия в реставрации: справ. пособие / М. К. Никитин, Е. П. Мельникова. - Л. : Химия, 1990. - 304 с.

7. Подъяпольский, С. С. Реставрация памятников архитектуры / С. С. Подъяпольский, Г. Б. Бессонов, Л. А. Беляев, Т. М. Постникова. - М. : Стройиздат, 1988. - 267 с.

8. Тур, Э. А. Жемчужины Брестчины: дворец Сапегов и Коссовский замок. Проблемы при реставрации и их решение / Э. А. Тур, С. В. Басов, В. Н. Казаков // Реставрация историко-культурных объектов в Брестской области как сохранение культурного наследия Республики Беларусь: сб. статей науч.-техн. семинара, Брест, 25 сентября 2019 г. / УО «Брест. гос. техн. ун-т»; под ред. Э. А. Тур. - Брест, 2019. - С. 66-72.
9. Тур, Э. А. К вопросу о сохранении объектов историко-культурного наследия в г. Бресте / Э. А. Тур, С. В. Басов // Вестник Брестского государственного технического университета. - 2018. - № 1: Строительство и архитектура. - С. 17-21.

10. Тур, Э. А. Комплексные научные исследования фасадов костела святых Петра и Павла в д. Рожанка Гродненской области / Э. А. Тур, С. В. Басов, Е. В. Счасная, В. В. Тричик // Вестник Брестского государственного технического университета. - 2020. - № 1: Строительство и архитектура. - С. 147-152.

11. Тур, Э. А. Исследование отделочных материалов фасадов костела святых Петра и Павла в д. Рожанка / Э. А. Тур, Е. В. Счасная, В. В. Тричик // Реставрация историко-культурных объектов в Брестской области как сохранение культурного наследия Республики Беларусь: сб. статей науч.-техн. семинара, Брест, 25 сентября 2019 г. / УО «Брест. гос. техн. ун-т»; под ред. Э. А. Тур. Брест, 2019. - С. 79-89.

12. Тур, Э. А. Руины усадьбы «Наднёман» в д. Наднёман Узденского района Минской области как объект историко-культурного наследия / Э. А. Тур, В. Н. Казаков, С. В. Басов, В.В.Тричик // Реставрация историко-культурных объектов как сохранение культурного наследия Республики Беларусь: сб. статей науч.-технич. семинара, Брест, 30 сентября 2020 г. / Брест. гос. техн. ун-т»; редкол.: под ред. Э. А. Тур [и др.]. - Брест, 2020. - С. 103-113.

\section{References}

1. Ivliev, A. A. Restavracionnye stroitel'nye raboty / A. A. Ivliev, A. A. Kalygin. - M. : ProfObrlzdat, 2001. -272 s.

2. Fryossel', F. Remont vlazhnyh i povrezhdyonnyh solyami stroi-tel'nyh sooruzhenij / F. Fryossel'. - M. : 000 «Pejnt-media», 2006. - 320 s.

3. Brok, T. Evropejskoe rukovodstvo po lakokrasochnym materia-lam i pokrytiyam / T. Brok, M. Groteklaus, P. Mishke. - per. s angl. pod red. L. N. Mashlyakovskogo. - M. : Pejnt-Media, 2004. - $548 \mathrm{~s}$.

4. Tur, E. A. Issledovanie mineral'nyh materialov, ispol'zovannyh pri postrojke dvorcovogo kompleksa Sapegov v Ruzhanah / E. A. Tur, S. V. Basov /I Vestnik Brestskogo gosudarstvennogo tekhnicheskogo universiteta. Brest : BrGTU, 2014. - № 1: Stroi-tel'stvo i arhitektura. - S. 88-91.

5. Tur, E. A. Restavraciya Kossovskogo dvorca Puslovskih i reshenie voznikshih pri etom tekhnicheskih problem / E. A. Tur, V. N. Kazakov, S. V. Basov // Vestnik Brestskogo gosudarstvennogo tekhnicheskogo universiteta. - 2017 - № 1: Stroitel'stvo i arhitektura. - S. 128-131.

6. Nikitin, N. K. Himiya v restavracii: sprav. posobie / M. K. Nikitin, E. P. Mel'nikova. - L. : Himiya, 1990 - 304 s.

7. Pod"yapol'skij, S. S. Restavraciya pamyatnikov arhitektury / S. S. Pod"yapol'skij, G. B. Bessonov, L. A. Belyaev, T. M. Postnikova. - M. : Strojizdat, 1988. $-267 \mathrm{~s}$.

8. Tur, E. A. ZHemchuzhiny Brestchiny: dvorec Sapegov i Kos-sovskij zamok. Problemy pri restavracii i in reshenie / E. A. Tur, S. V. Basov, V. N. Kazakov // Restavraciya istoriko-kul'turnyh ob"ektov v Brestskoj oblasti kak sohranenie kul'turnogo naslediya Respubliki Belarus': sb. statej nauch.tekhn. seminara, Brest, 25 sentyabrya 2019 g. / UO «Brest. gos. tekhn. un-t»; pod red. E. A. Tur. - Brest, 2019. - S. 66-72.

9. Tur, E. A. K voprosu o sohranenii ob"ektov istoriko-kul'turnogo naslediya v g. Breste / E. A. Tur, S. V. Basov // Vestnik Brestskogo gosudarstvennogo tekhnicheskogo universiteta. - 2018. - № 1: Stroitel'stvo i arhitektura. - S. 17-21.

10. Tur, E. A. Kompleksnye nauchnye issledovaniya fasadov kostela svyatyh Petra i Pavla v d. Rozhanka Grodnenskoj oblasti / E. A. Tur, S. V. Basov, E. V. Schasnaya, V. V. Trichik // Vestnik Brestskogo gosudarstvennogo tekhnicheskogo universiteta. - 2020. - № 1: Stroitel'stvo i arhitektura. - S. 147-152.

11. Tur, E. A. Issledovanie otdelochnyh materialov fasadov kostela svyatyh Petra i Pavla v d. Rozhanka / E. A. Tur, E. V. Schasnaya, V. V. Trichik // Restavraciya istoriko-kul'turnyh ob"ektov v Brestskoj oblasti kak sohranenie kul'turnogo naslediya Respubliki Belarus': sb. statej nauch.-tekhn. seminara, Brest, 25 sentyabrya $2019 \mathrm{~g}$. / UO «Brest. gos. tekhn. un-t»; pod red. E. A. Tur. - Brest, 2019. - S. 79-89.

12. Tur, E.A. Ruiny usad'by "Nadnyoman» v d. Nadnyoman Uzdenskogo rajona Minskoj oblasti kak ob"ekt istoriko-kul'turnogo naslediya / E. A. Tur, V. N. Kazakov, S. V. Basov, V. V. Trichik // Restavraciya istoriko-kul'turnyh ob"ektov kak sohranenie kul'turnogo naslediya Respubliki Belarus': sb. statej nauch.-tekhnich. seminara, Brest, 30 sentyabrya $2020 \mathrm{~g}$. / Brest. gos. tekhn. un-t»; redkol.: pod red. E.A. Tur [i dr.]. - Brest, 2020. - S. 103-113.

Материал поступил в редакцию 22.01.2021 